\title{
Analisis implementasi wakaf wasiat polis asuransi syariah di lembaga wakaf al-Azhar Jakarta
}

\author{
Siska Lis Sulistiani \\ Fakultas Syariah Universitas Islam Bandung \\ E-mail: siscaassidq@yahoo.co.id \\ DOI: 10.18326/ijtihad.v17i2.285-299
}

\begin{abstract}
Waqf in Islam is one way to invest in property for the sake of the world and the hereafter. The development of waqaf must still be in the sharia corridor so that its ubudiyah and iqtishadiyah values remain. Islamic law will not be known even as DSN MUI has just released its fatwa in October 2016 which is the investment benefit and sharia life fatwa, but some sharia insurance institutions and wakaf institutions in Indonesia first applied this form of waqf. The legal status of a wakaf law on Islamic insurance policy under Islamic law includes productive wakaf. However, in terms of its ownership element as a waqf object has not been fully owned by wakif so ulama differed in opinion, although in principle has been owned by wakif, but still opens the dispute space because the waqf object is not yet fully owned. The wakaf law of syariah insurance policy itself is still potentially canceled by wakif or by sharia insurance if one of them wakif get difficulty paying the premium before maturity. Implementation of waqf syariah insurance policy at Al-Azhar Wakaf Institute Jakarta has not yet fully complied with the rules of Fatwa DSN MUI because the fatwa has just come out in the end of 2016 and socialized in early 2017, whereas the wakaf will be known as sharia insurance policy in the community.
\end{abstract}

Wakaf dalam Islam adalah salah satu cara menginvestasikan harta untuk kepentingan dunia dan akhirat. Perkembangan wakaf tersebut tetap harus dalam koridor syariat sehingga nilai ubudiyyah dan iqtisădiyyahnya tetap ada. Wakaf wasiat asuransi syariah menjadi bentuk wakaf baru yang belum banyak diketahui bahkan DSN MUI pun baru mengeluarkan fatwanya pada Oktober 2016 yaitu fatwa manfaat investasi dan asuransi jiwa syariah, namun dibeberapa lembaga asuransi syariah dan lembaga wakaf di Indonesia justru lebih dulu mengaplikasikan bentuk wakaf ini. Kedudukan hukum wakaf wasiat polis asuransi syaria menurut hukum Islam termasuk wakaf produktif. Namun, dari sisi unsur kepemilikannya sebagai objek wakaf belum sepenuhnya dimiliki oleh wakif sehingga ulama berbeda pendapat, walaupun secara prinsip telah dimiliki oleh wakif, namun masih membuka ruang sengketa karena objek wakaf tersebut belum dimiliki sepenuhnya. Akad wakaf wasiat polis asuransi syariah sendiri masih berpotensi dibatalkan 
oleh wakif maupun oleh pihak asuransi syariah salah satunya jika pihak wakif mendapatkan kesulitan dalam membayar premi sebelum jatuh tempo. Implementasi wakaf wasiat polis asuransi syariah di Lembaga Wakaf Al-Azhar Jakarta belum sepenuhnya mengikuti aturan dalam Fatwa DSN MUI dikarenakan fatwa tersebut baru keluar diakhir 2016 dan disosialisasikan di awal 2017, sedangkan wakaf wasiat polis asuransi syariah ini sudah dikenal di masyarakat sejak 2012.

Keywords: Wakaf; Islamic insurance; law of syariah

\section{Pendahuluan}

Wakaf merupakan suatu instrumen ekonomi Islam yang belum diberdayakan secara optimal di Indonesia. Sedangkan di negara lain seperti Mesir, Arab Saudi, Yordania, Turki, Bangladesh, Mesir, Malaysia dan Amerika Serikat, wakaf telah dikembangkan sebagai salah satu lembaga sosial ekonomi Islam yang dapat membantu berbagai kegiatan umat dan mengatasi masalah umat seperti kemiskinan (Prihatini, 2005; 131). Selain aspek ubudiyyah yang terkandung dalam wakaf, nilai iqtișädiyyah (ekonomi) pun menjadi aspek penting dalam pengembangan bentuk wakaf dan pemanfaatan hasilnya. Oleh karena itu, potensi wakaf ini merupakan hal yang menarik untuk terus dikembangkan mengingat wakaf pada hakikatnya harus produktif dalam bentuknya maupun dalam penyalurannya.

Wakaf memainkan peran ekonomi dan sosial yang sangat penting dalam sejarah Islam. Wakaf berfungsi sebagai sumber pembiayaan bagi masjid, sekolah, pengkajian dan penelitian, rumah sakit, pelayanan sosial dan pertahanan (Anwar, 2007: 75). Di era globalisasi ini dengan tantangan ekonomi yang terus menuntut persaingan, melahirkan dampak tingginya angka kemiskinan di Indonesia Badan Pusat Statistik (BPS) mencatat jumlah penduduk miskin Indonesia per September 2015 mencapai 28,51 juta orang, bertambah 780 ribu orang dibanding September 2014 sebanyak 27,73 juta orang (antaranews.com). Islam sebagai ajaran yang rahmatan li al-'álamin, tidak hanya mengatur masalah ubudiyyah saja, namun mengatur juga masalah amaliyyah khususnya masalah aspek ekonomi. Selain instrumen zakat yang dikenal dalam 5 komponen rukun Islam, dikenal juga wakaf sebagai bagian dari bentuk filantropi Islam.

Lembaga wakaf selama ini dianggap sebagai lembaga nirlaba yang tidak berkonsentrasi pada profit oriented, dan hanya fokus pada masalah ibadah sehingga pengembangannya hanya berhenti pada pembangunan tempat ibadah saja, sedangkan potensi wakaf terakhir di 2015 
menurut Kepala Divisi Pengelolaan dan Pemberdayaan Wakaf, Robbiyantono (Antaranews.com, 2015) menjelaskan bahwa dari data yang dihimpun diketahui tanah tanah wakaf di Indonesia tercatat seluas 4,2 miliar meter persegi di 42.3000 lokasi. Selain itu, jika umat Islam yang akan berwakaf 5 persen dari 190 juta, sekitar 9,5 juta jiwa, maka jika masing-masing mengeluarkan wakaf Rp 100.000 setiap bulan, maka akan terkumpul Rp 950 miliar per bulan dan Rp 11,4 triliun per tahun. Dana sebesar itu sangat bermanfaat bagi kemaslahatan umat untuk program pengentasan kemiskinan, pemberian beasiswa berprestasi, dan pemberikan kecakapan hidup (life skills) kepada kaum pengangguran di negeri ini serta ini merupakan potensi wakaf yang sangat besar, di luar harta wakaf benda bergerak lain yang dapat diberdayakan.

Terkait dengan persoalan wakaf, di sini pemerintah memberikan perhatian yang sangat serius dengan mengeluarkan Peraturan Pemerintah No. 42 tahun 2006 tentang Pelaksanaan Undang-Undang No. 41 tahun 2004 tentang Wakaf karena selama ini tradisi masyarakat Indonesia dalam pengelolaan wakaf masih cenderung bersifat konsumtif dan pengelolaan secara produktif yang diharapkan oleh pemerintah belum maksimal. Selain itu, persepsi masyarakat dalam memahami wakaf masih terikat dan tersekat dengan pemahaman lama yang hampir mendominasi pemikiran masyarakat muslim Indonesia.

Demi menggali potensi dan manfaat wakaf serta pengelolaannya secara produktif digalilah wakaf dari sisi asuransi khususnya dari asuransi syariah dalam hal ini adalah polis asuransi bagi seseorang yang meninggal dunia dan meninggalkan sebagian hartanya hasil dari klaim di lembaga asuransi syariah tertentu. Dari dana klaim tersebut mengandung potensi yang besar saat disalurkan dalam bentuk wakaf selain menjadi amal jariyah bagi si mayit dapat juga bermanfaat bagi umat disertai bentuk pengelolaan yang efektif dan produktif untuk nilai yang jauh lebih besar.

Praktik Wakaf wasiat polis asuransi syariah sejak 2012 sudah mulai disosialisasikan dan dipraktikan dibeberapa lembaga wakaf, khususnya di Lembaga Wakaf Al-Azhar Jakarta. Namun, memiliki legalitas wakaf karena DSN MUI pun baru mengeluarkan Fatwa terkait manfaat investasi dan asuransi jiwa syariah di oktober 2016. 
ljtihad: Jurnal Wacana Hukum Islam dan Kemanusiaan, Volume 17, No. 2, Desember 2017: 285-299

\section{Metode penelitian}

Pendekatan penelitian ini adalah penelitian kualitatif, melalui pendekatan penelitian hukum yuridis normatif yang mencakup penelitian terhadap asas-asas hukum, sistematika hukum, taraf sinkronisasi hukum, sejarah hukum dan perbandingan hukum. Spesifikasi penelitian ini adalah penelitian deskriptif analitis yang merupakan penelitian untuk menggambarkan dan menganalisa masalah yang ada dan termasuk dalam jenis penelitian kepustakaan (library research) yang akan disajikan secara deskriptif. Penelitian ini dilaksanakan di Yayasan Al-azhar Jakarta di bidang khusus penanganan masalah pemberdayaan wakaf. Penelitian hukum yuridis normatif ini, data yang diperlukan berupa data sekunder adapun wawancara dengan berbagai pihak di antaranya lembaga Wakaf Al-azhar sebagai pelengkap. Adapun data sekunder yang digunakan yaitu sumber hukum primer, sekunder dan tersier yang berupa bahan-bahan hukum yang dibutuhkan. Metode pengumpulan data melalui studi kepustakaan (library research) yaitu jenis penelitian yang data-datanya diperoleh dari buku, kitab, majalah, surat kabar, jurnal dan catatan lainnya yang memiliki relevansi dengan permasalahan yang akan dibahas, serta dianalisis melalui metode kualitatif deskriptif.

\section{Gambar 1.}

\section{Metodologi Penelitian}

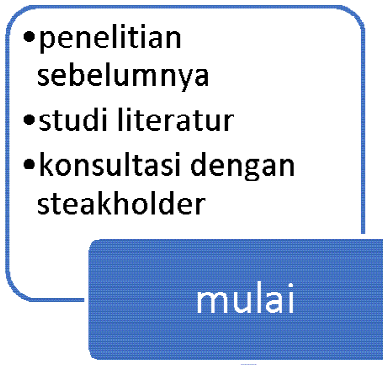

\section{pengumpulan}
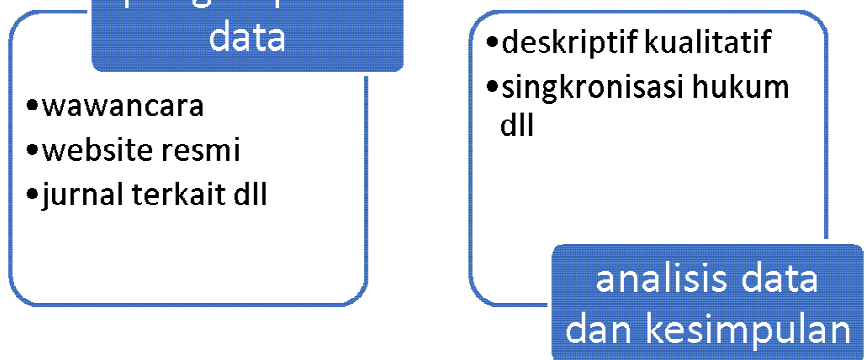


\section{Hukum wakaf produktif melalui wakaf wasiat polis asuransi syariah menurut hukum Islam}

Wakaf secara bahasa berarti menahan atau mencegah. Dalam terminologi hukum Islam, kata tersebut didefinisikan sebagai suatu tindakan penahanan dari penggunaan dan penyerahan aset di mana seseorang dapat memanfaatkan atau menggunakan hasilnya untuk tujuan amal, sepanjang barang tersebut masih ada. Namun, banyak dari aliran Hanafiah memandang wakaf sebagai mengambil sebagian dari properti kepemilikan Allah SWT dan mendermakannya kepada orang lain. Dalam bahasa hukum kontemporer, wakaf berarti pemberian, dilakukan atas kehendak ahli waris, dengan satu niat memenuhi panggilan ketakwaan. Wakaf juga didefinisikan sebagai harta yang disumbangkan untuk berbagai tujuan kemanusiaan untuk selamanya, atau penyerahan aset tetap oleh seseorang sebagai bentuk manifestasi kepatuhan terhadap agama (Abdul Mannan, 2001: 29).

Pada hakikatnya wakaf seharusnya bersifat produktif karena ia menahan dan memberdayakan harta yang dijadikan aset untuk melahirkan manfaat lain, tanpa mengurangi inti dari harta tersebut. Namun kini dikenal istilah wakaf produktif yaitu menahan harta untuk diberdayakan dalam bentuk-bentuk produksi maupun bentuk lainnya yang dapat menghasilkan manfaat lebih, sesuai tujuan wakaf tanpa mengurangi harta inti wakaf (Sulistiani, 2016).

Ibnu Umar menuturkan bahwa Umar pernah mendapat kebun kurma di Khaibar. Umar ingin menyedekahkannya. Lalu ia bertanya kepada Rasulullah. Rasul menjawab: Jika engkau mau, engkau dapat menahan pokoknya dan bersedekah dengannya" (HR al-Bukhari, Muslim, at-Tirmidzi, an-Nasaa'i, Ibnu Majah, Ahmad)

Wakaf produktif di Indonesia terus berkembang, seiring bertambahnya kemajuan industri ekonomi syariah yang diharapkan dapat menjawab krisis ekonomi masyarakat di Indonesia. Perkembangan wakaf ini salah satunya dalam industri asuransi syariah. Asuransi syariah menjadi salah satu produk yang saat ini dinilai memliki potensi ekonomi yang dapat memberikan manfaat bukan hanya bagi nasabah secara dunia saja namun dapat memberi manfaat akhirat atau bersifat amal jariyah.

Sementara itu pada asuransi syariah akad yang melandasinya akad tolong-menolong bukan akad jual-beli atau akad mu'awadhah sebagaimana halnya pada asuransi konvensional. 
ljtihad: Jurnal Wacana Hukum Islam dan Kemanusiaan, Volume 17, No. 2, Desember 2017: 285-299

Dengan menciptakan instrumen baru dalam asuransi syariah untuk menyalurkan dana kebajikan melalui akad tabarru'.

Dari penjelasan tersebut menjadikan asuransi syariah berbeda dengan praktik asuransi komersial atau asuransi konvensional. Mengingat dari bentuk akadnya pun berbeda, serta harus terbebas dari riba, gharar dan tadlis. Adapun akad yang digunakan dalam asuransi syariah yaitu akad musyarakah bagi sesama pemegang polis asuransi syariah, wakalah bi alujrah atau mudharabah, serta hibah (Tirmizi, 2016: 297).

Selain itu, tingginya minat masyarakat dikarenakan dalam prinsipnya, asuransi syariah menggunakan prinsip ta'awun (tolong-menolong) dan al-ta'min (rasa aman) sebagaiman firman Allah SWT dalam QS [5] Al Maidah: 2

Artinya: ... dan tolong-menolonglah kamu dalam (mengerjakan) kebajikan dan takwa, dan jangan tolong-menolong dalam berbuat dosa dan pelanggaran. dan bertakwalah kamu kepada Allah, Sesungguhnya Allah Amat berat siksa-Nya. (QS [5] Al Maidah: 2)

Pada prinsipnya memang diantara sesama manusia diperintahkan untuk tolong-menolong dalam hal kebaikan, bukan dalam hal yang tidak baik. Kemudian ada seruan untuk bertakwa kepada Allah Swt. Adapula hadits juga yang membicarakan perkara seperti ini, diantaranya yaitu:

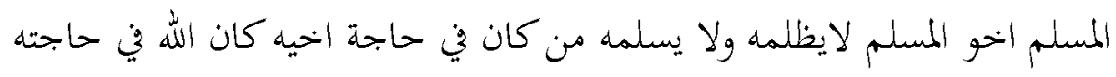

Artinya:"Seorang muslim dengan muslim yang lain adalah bersaudara, ia tidak boleh berbuat dzalim dan aniaya kepada saudaranya yang muslim, barang siapa yang membantu memenubi hajat (kebutuhan) saudaranya, maka Allah SWT akan memenubi hajatnya" (HR. Bukhari dan Muslim).

Adapun istilah wakaf wasiat polis asuransi diambil dari kata wakaf yang menurut istilah syara adalah menahan harta yang mungkin diambil manfaatnya tanpa menghabiskan atau merusakkan bendanya dan digunakan untuk kebaikan (al-Shana'i, t.t: 114). Wakaf wasiat adalah suatu perencanaan wakaf dengan mewasiatkan secara legal sebagian dari kepemilikan aset wakif ketika yang bersangkutan meninggal dunia namun tetap dapat menikmati manfaat dari aset yang diwakafkan tersebut selama wakif tersebut hidup (Lembaga Wakaf Al-Azhar, 2016). Sedangkan, pengertian polis asuransi adalah sebuah perjanjian asuransi atau pertanggungan yang bersifat konsensual (terdapat kesepakatan), dibuat secara tertulis didalam 
suatu akta dari pihak yang telah mengadakan perjanjian. Di akta yang telah dibuat secara tertulis tersebut dinamakan "Polis". Sehingga polis merupakan sebuah tanda bukti perjanjian dalam pertanggungan yang menjadi bukti tertulis. Adapun pengertian dari wakaf polis asuransi adalah mewakafkan sebagian nilai yang akan diterima jika polis asuransi yang dimiliki seseorang telah dicairkan (Sulistiani, 2016:3).

Sejak mulai dikenalkannya istilah wakaf wasiat polis asuransi syariah selama 4 tahun hingga 2016 istilah wakaf wasiat polis asuransi syariah ini belum memiliki legalitas terkait fatwa terkait di Indonesia. Dan pada tahun 2016 Dewan Syariah Nasional MUI mengeluarkan fatwanya dengan No. 106/DSN-MUI/X/2016 tentang wakaf manfaat asuransi dan manfaat investasi pada asuransi jiwa syariah yang ditandatangi pada tanggal 1 Oktober 2016, fatwa ini sekaligus menjawab tentang praktik wakaf wasiat polis asuransi syariah yang telah dikembangkan dan disosialisasikan sejak tahun 2012. Setelah munculnya fatwa tersebut, justru DSN MUI tidak menggunakan istilah wakaf wasiat polis asuransi syariah namun lebih memilih menggunakan istilah wakaf manfaat asuransi dan manfaat investasi pada asuransi jiwa syariah.

Dalam fatwa DSN MUI terkait manfaat asuransi dan manfaat investasi syariah tersebut jelas dibedakan antara istilah manfaat asuransi yaitu sejumlah dana yang bersumber dari dana tabarru' yang diserahkan kepada pihak yang mengalami musibah atau pihak yang ditunjuk untuk menerimanya serta maximal besaran untuk diwakafkan adalah 45\%. Adapun manfaat investasi adalah sejumah dana yang diserahkan kepada peserta program asuransi yang berasal dari kontribusi investasi peserta dan hasil investasinya. Serta maksimal yang boleh diwakafkan paling banyak $1 / 3$ dari total kekayaan dan atau tirkah, kecuali disepakati lain oleh semua ahli waris.

Kemanfaatan dari asuransi sebetulnya juga dapat dirasakan oleh peserta asuransi yang telah meninggal dunia, tentunya bentuk manfaatnya yang tidak berupa unsur materiil. Lembaga asuransi syariah dapat melakukan channeling dengan lembaga wakaf yang tersebar di seluruh Indonesia. Dana premi yang terkumpul dari para peserta, sebagian dapat diinvestasikan ke lembaga wakaf, kemudian oleh lembaga wakaf dana tersebut dipergunakan untuk pembangunan rumah ibadah, membangun fasilitas pendidikan Islam atau membangun pusat bisnis yang dengan keuntungannya dapat digunakan untuk kemaslahatan kaum muslimin. 
ljtihad: Jurnal Wacana Hukum Islam dan Kemanusiaan, Volume 17, No. 2, Desember 2017: 285-299

Sehingga ada "manfaat non-materiil" yang dapat diberikan kepada peserta asuransi yang telah meninggal (Habibi, 2017: 143).

Dalam wakaf asuransi ini menggunakan dua dimensi yaitu dimensi dunia dan akhirat. Ketika calon wakif (orang yang berwakaf) melalui polis asuransi maka akad yang digunakan ada dua yaitu: 1) Akad wakaf untuk wakaf produktif sebagaian dari nilai Polis Asuransi yang meliputi uang pertanggungan (UP) dan nilai tunai saat jatuh tempo. 2) Akad amal kebaikan/charity untuk kepentingan wakif, keluarga wakif, kepentingan umum, sebagaian dari nilai Polis Asuransi (UP dan Nilai Tunai) saat jatuh tempo (Lembaga Wakaf Al-Azhar, 2016).

Menurut Kompilasi Hukum Islam (KHI) buku III tentang hukum perwakafan pasal 215 yang dimaksud wakaf adalah perbuatan hukum seseorang atau kelompok orang atau badan hukum yang memisahkan sebagian dari benda miliknya dan melembagakanya untuk selama-selamanya guna kepentingan ibadat atau keperluan umum lainnya sesuai dengan ajalah Islam (KHI, 99).

Adapun syarat-syaratnya sebagai wakif sebagaimna yang diatur dalam ketentuan pasal 217 ayat 2 Kompilasi Hukum Islam yaitu apabila yang menjadi wakif itu badan-badan hukum Indonesia, maka yang bertindak untuk dan atas namanya adalah pengurusnya yang sah menurut hukum Islam. Mengenai benda yang diwakafkan bukan benda yang sembarangan, melainkan benda milik, yang bebas dari segala: pembebanan, ikatan, dan sengketa.

Terkait wakaf wasiat polis asuransi syariah yang menjadi sorotan adalah mengenai objek wakaf. Dalam wakaf wasiat polis asuransi syariah harta yang diwakafkan belum secara utuh dimiliki oleh wakif, walaupun secara prinsip dimiliki wakif sebagai nasabah asuransi syariah. Terkait syarat harta wakaf yang diwakafkan tidak ada perbedaan pendapat dikalangan fuqaha bahwa wakaf harus berasal dari harta milik pewakaf sendiri (hak milik). Untuk itu, seorang pewakaf haruslah pemilik sah harta yang akan diwakafkan atau ia adalah orang yang berhak untuk melaksanakan tindakan wakaf terhadap suatu harta jika ia menjadi wakil pemilik harta wakaf atau pelaksana wasiat seseorang (al-Kabisi, 2004: 251).

Hanya saja, para fuqaha berbeda pendapat tentang keharusan terpenuhinya syarat ini pada waktu pelaksanaan wakaf antara lain (al-Kabisi, 2004: 252): a) Ulama Malikiyah 
mengatakan bahwa tidak harus harta tersebut milik dari pewakaf saat dia mewakafkannya. Berdasarkan hal ini, jika seseorang mengatakan telah memiliki rumah si A, dan menyatakan bahwa rumah itu akan menjadi wakaf, lalu orang tersebut memilikinya, maka sah wakafnya. Seperti halnya jika seseorang berkata bahwa apa yang sedang dibangun pada toko si B adalah wakaf, kemudian dibangunlah toko itu, maka sah wakafnya dan tidak perlu lagi membuat satu pernyataannya bersifat umum, maka wakafnya tidak sah. Hal itu sama dengan pemaksaan terhadap seseorang yang memang dilarang oleh agama. Jadi, tidak sah jika seseorang mengatakan bahwa seluruh hartanya dalam bentuk bangunan atau lainnya dan setiap harta yang menjadi miliknya adalah harta wakaf. b) Pendapat jumhur mengatakan, agar wakaf itu sah, maka harta wakaf itu haruslah merupakan hak milik dari wakif saat mewakafkan hartanya dengan sebenar-benarnya. Jika tidak demikian, maka wakafnya batal.

Selain itu, jika harta hadiah diwakafkan sebelum dimiliki oleh penerima hadiah, maka wakafnya tidak sah. Sebab, harta itu belum menjadi milik orang yang diberi hadiah, kecuali jika dia telah memiikinya atau menerima dari pemberi hadiah. Jika dia mewakafkan hadiah yang belum diterimanya, sama saja dengan mewakafkan harta yang belum menjadi miliknya. Adapun terkait wakaf wasiat, jika seseorang yang diberikan wasiat atas suatu tanah atau benda belum menjadi miliknya resmi dari harta itu, kecuali pemberi wasiat telah meninggal dunia. Harta wasiat belum dapat dimiliki oleh seseorang kecuali setelah si pemberi wasiat meninggal (al-Kabisi, 253).

Wakaf wasiat akadnya tidak berlaku kecuali setelah orang tersebut meninggal dunia. Selama dia masih hidup, dia boleh mengubah, mengganti atau membatalkannya. Setelah dia meninggal, jika ahli warisnya mengizinkan, maka akad wakaf tersebut dilaksanakan. Namun, jika mereka tidak mengizinkan maka yang diwakafkan hanya sepertiga dari harta peninggalannnya (Al-Utsaimin, 2008: 89).

Wakaf wasiat polis asuransi syariah di Indonesia yaitu mewakafkan hasil manfaat dan investasi syariah sekaligus, dengan menyerahkan polis sebagai bentuk akad wakaf kepada Nadzir yang akan diserahkan besaran wakaf realnya jika wakif meninggal dunia atau jika wakif masih tetap hidup dalam jangka waktu tertentu hasil manfaat dan investasi syariah itu tetap diserahkan sebagai wakaf dengan mengacu pada ketentuan fatwa DSN MUI No. 106/DSN-MUI/X/2016. Hanya saja, dalam perjalanan setelah akad tersebut jika wakif 
ljtihad: Jurnal Wacana Hukum Islam dan Kemanusiaan, Volume 17, No. 2, Desember 2017: 285-299

mendapati kesulitan membayar premi asuransi sehingga mengakibatkan wakaf tersebut dapat dibatalkan. Hal ini lah yang dikhawatirkan karena harta real wakaf belum dimiliki sepenuhnya oleh si wakif, sehingga mengakibatkan pembatalan wakaf.

\section{Gambar 2}

\section{Skenario kemitraan antara Lembaga Takaful (asuransi) dengan calon mitra (Habibi, 2017, 152)}

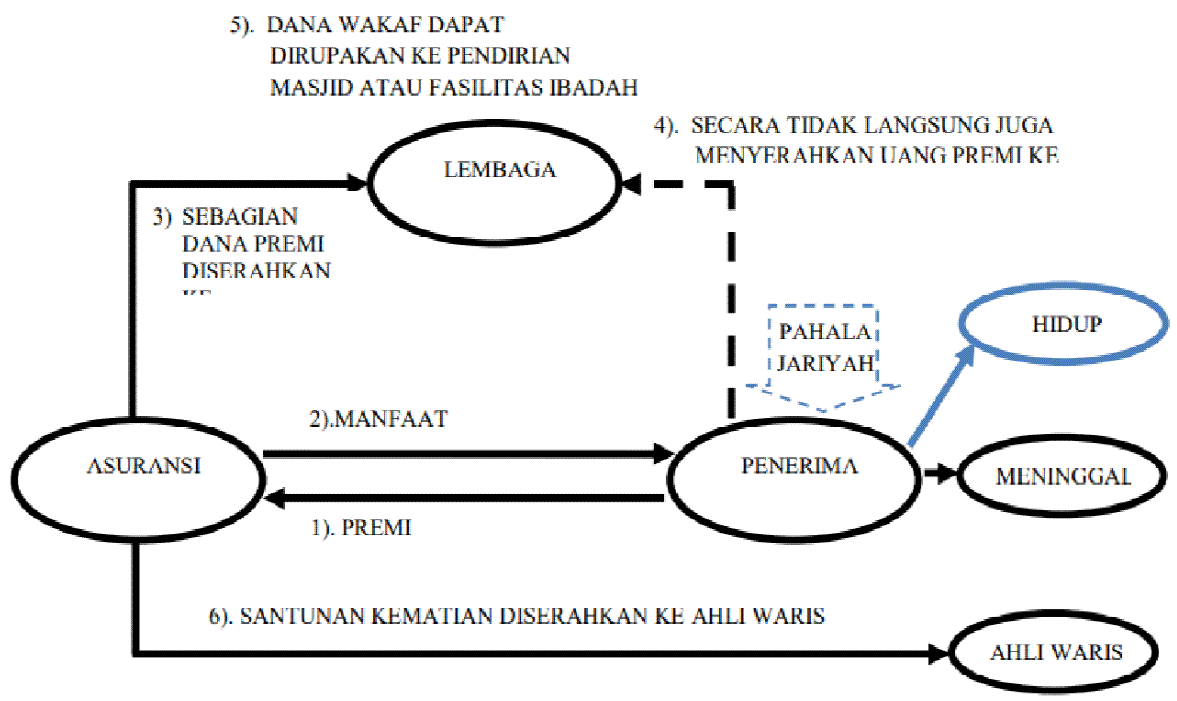

Hal pokok yang bisa digaris bawahi dari keberadaan prinsip-prinsip ini adalah ketidakmampuan memenuhinya dapat menyebabkan batalnya perjanjian. Guna melihat prinsip-prinsip ini dari sudut pandang hukum perjanjian Islam, syarat perjanjian ('aqad) dibagi menjadi dua. Pertama, syarat adanya (terbentuknya) aqad, yaitu dimana apabila syarat ini tidak terpenuhi akad akan tidak ada atau tidak terbentuk dan akadnya disebut batal. Kedua syarat sahnya akad, yaitu syarat dimana apabila tidak terpenuhinya lantas perjanjian itu tidak atau tidak terbentuk. Bisa saja akadnya ada dan telah terbentuk karena syarat adanya (terbentuknya) telah terpenuhi misalnya, hanya saja akad dia anggap belum sempurna dan masih memilih kekurangan dan dalam keadaan demikian akad tersebut oleh ahli-ahli hukum Hanafi disebut dengan akad fasid, dan harus dibatalkan (Ismanto, 2009, 192). Jika mengacu 
pada pendapat madzhab hanafi tersebut maka akad wakaf wasiat polis asuransi syariah tersebut akad fasid.

"Kaum muslimin terikat dengan syarat-syarat yang mereka buat kecuali syarat yang mengharamkan yang halal atau menghalalkan yang haram." (HR. Tirmidzi dari 'Amr bin 'Auf).

Namun dengan besarnya maslahah yang besar dari hasil wakaf wasiat polis asuransi syariah baik bagi aset wakaf maupun bagi lembaga asuransi syariah, sehingga Dewan Syariah Majlis Ulama Indonesia melihat lebih besar maslahatnya dengan syarat adanya ketentuan khusus dalam praktek akad wakaf wasiat polis asuransi syariah yaitu dengan istilah bahwa manfaat asuransi dan manfaat investasinya sudah dimiliki wakif secara prinsip.

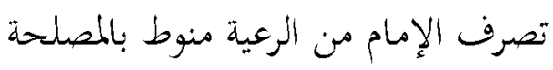

"Tindakan penguasa terhadap rakyatnya harus dikaitkan dengan kemaslahatan."

\section{Analisis implementasi wakaf produktif melalui wakaf wasiat polis asuransi syariah di lembaga wakaf al-Azhar Jakarta}

Pada dasarnya wakaf itu haruslah produktif dalam arti harus berkembang tanpa mengurangi aset intinya serta dimanfaatkan sesuai dengan peruntukannya (mauquf alaih). Orang yang pertama melakukan perwakafan adalah Umar bin al Khaththab mewakafkan sebidang kebun yang subur di Khaybar. Kemudian kebun itu dikelola dan hasilnya untuk kepentingan masyarakat. Tentu wakaf ini adalah wakaf produktif dalam arti mendatangkan aspek ekonomi dan kesejahteraan masyarakat. Ironinya, di Indonesia banyak pemahaman masyarakat yang megasumsikan wakaf adalah lahan yang tidak produktif bahkan mati yang perlu biaya dari masyarakat, seperti kuburan, masjid.

Begitu pula Wakaf Al-Azhar lahir terinspirasi oleh pengelolaan Wakaf Al Azhar Kairo di Mesir yang berkembang pesat dengan mengelola wakaf produktif berupa: rumah sakit, apartemen, perkebunan. Demikian juga di Indonesia wakaf al Azhar sedang menggalakan gerakan wakaf nasional berupa: wakaf pohon jati, apartemen, pom bensin, kapal tanker, pesawat terbang, wakaf perusahan, dinar dan lain-lain.

Wakaf Polis Asuransi ialah mewakafkan sebagian nilai yang akan diterima jika polis asuransi yang telah dimiliki telah dicairkan (Lembaga Wakaf Al-Azhar, 2016). Dalam hal ini 
ljtihad: Jurnal Wacana Hukum Islam dan Kemanusiaan, Volume 17, No. 2, Desember 2017: 285-299

masyarakat yang memiliki polis asuransi dari perusahaan asuransi yang memiliki produk syariah setelah dijadikan polis dan menjadi surat berharga maka manfaatnya atau uang pertanggunannya dan manfaat lainnya itu akan diwakafkan.

Pada wakaf wasiat polis asuransi syariah, lembaga wakaf Al-Azhar memberikan ketentuan-ketentuan mewakafkan sebagian nilai polisnya dengan mengunakan wakaf produktif, adapun ketentuan dari wakaf polis asuransi adalah sebagai berikut:

Pertama, Nilai Polis Asuransi < 250.000.000 (wakaf khairi); a) Wakaf Khairi 50 \% dari nilai polis saat jatuh tempo; b) Layanan Jenazah All In; c) (Memandikan,mengkafani, menyolatkan, menguburkan serta ta'jiyah 3 hari bersama ustad dan dan juga snack);

Kedua, Polis Asuransi Plus (beasiswa) Ketentuan: UP Rp.500 juta s/d Rp. 1 milyar. Polis Asuransi yang diwakafkan dengan jumlah 500 juta atau 1 milyar, Sebagian (50\%) sebagai Wakaf Produktif Sebahagian (50\%). Beasiswa untuk anak-anak tersayang atau anak yang ditunjuk sampai perguruan tinggi di Al-Azhar bila Wakif lebih dahulu dipanggil sang Khaliq atau disekolah lain dengan standar maksimal sekolah Al-Azhar.

Ketiga, Wakaf asuransi plus pemakaman (AMG). Polis Asuransi yang diwakafkan ke wakaf ini dengan jumlah > 250 juta maka akan ada kesepakatan bersama antara wakif dan pengelola wakaf Al Azhar sebagaimana 1/2 sebagai wakaf khairi kemudian 1/2 nya lagi sedekah untuk Pemakaman AMG dan kepentingan umum lainnya. Ketentuan tersebut menjadi acuan kepada para calon wakif untuk mengetahui skema wakaf yang akan diwakafkan dalam bentuk wakaf wasiat polis asuransi syariah di Al-Azhar.

Pada hakikatnya Dewan Syariah Nasional MUI melalui fatwanya No. 106/DSN-MUI/ $\mathrm{X} / 2016$ tentang wakaf manfaat asuransi dan manfaat investasi pada asuransi jiwa syariah yang ditandatangi pada tanggal 1 Oktober 2016, memiliki ketentuan terkait wakaf ini yaitu:

Pertama, Ketentuan Wakaf Manfaat Asuransi; a) Pihak yang ditunjuk untuk menerima manfaat asuransi menyatakan janji yang mengikat (wa'd mulzim) untuk mewakatkan manfaat asuransi; b) Manfaat asuransi yang boleh diwakatkan paling banyak 45\% dari total manfaat asuransi; c) Semua calon penerima manfaat asuransi yang ditunjuk atau penggantinya menyatakan persetujuan dan kesepakatannya; d) lkrar wakaf dilaksanakan setelah manfaat asuransi secara prinsip sudah menjadi hak pihak yang ditunjuk atau penggantinya. 
Kedua, Ketentuan Wakaf Manfaat Investasi; a) Manfaat investasi boleh diwakatkan oleh peserta asuransi; b) Kadar jumlah manfaat investasi yang boleh diwakafkan paling banyak sepertiga (113) dari total kekayaan dan/atau tirkah, kecuali disepakati lain oleh semua ahli waris.

Ketiga, Ketentuan Ujrah terkait dengan produk wakaf; a) Ujrah tahun pertama paling banyak 45\% dari kontribusi reguler; b) Akumulasi ujrah tahun berikutnya paling banyak $50 \%$ dari kontribusi reguler.

Dari ketentuan tersebut menunjukan bahwa besaran wakaf wasiat polis asuransi menjadi terbatas tidak bisa seluruhnya, yaitu maximal 45\% untuk wakaf pada manfaat asuransi serta maximal 1/3 dari manfaat investasi asuransi jiwa syariah, kecuali disepakati oleh para ahli waris. Hal ini yang menjadi rambu-rambu dari pihak dewan syariah MUI mengenai praktik wakaf wasiat polis asuransi syariah tersebut. Mengingat praktik wakaf ini sudah terlebih dahulu dikenal dimasyarakat sebelum keluarnya aturan berdasarkan fatwa MUI sehingga seharusnya wakaf wasiat polis asuransi syariah di Al-Azhar tersebut mengembalikan ketentuan porsi wakaf dari manfaat asuransi dan manfaat investasi sesuai fatwa yang berlaku. Selain itu, mengingat pihak lembaga wakaf Al-Azhar melalui surat yang diajukannya pada pihak MUI sebagai salah satu peminta fatwa (mustafti) dalam proses keluarnya fatwa No. 106/ DSN-MUI/X/2016 tentang wakaf manfaat asuransi dan manfaat investasi pada asuransi jiwa syariah sehingga menjadikan mengikat isi fatwa tersebut bagi peminta fatwa.

Dari ketentuan tersebut menunjukan bahwa besaran wakaf wasiat polis asuransi menjadi terbatas tidak bisa seluruhnya, yaitu maximal 45\% untuk wakaf pada manfaat asuransi serta maximal 1/3 dari manfaat investasi asuransi jiwa syariah, kecuali disepakati oleh para ahli waris. Hal ini yang menjadi rambu-rambu dari pihak dewan syariah MUI mengenai praktik wakaf wasiat polis asuransi syariah tersebut. Mengingat praktik wakaf ini sudah terlebih dahulu dikenal dimasyarakat sebelum keluarnya aturan berdasarkan fatwa MUI sehingga seharusnya wakaf wasiat polis asuransi syariah di Al-Azhar tersebut mengembalikan ketentuan porsi wakaf dari manfaat asuransi dan manfaat investasi sesuai fatwa yang berlaku. Selain itu, mengingat pihak lembaga wakaf Al-Azhar melalui surat yang diajukannya pada pihak MUI sebagai salah satu peminta fatwa (mustafti) dalam proses keluarnya fatwa No. 106/ DSN-MUI/X/2016 tentang wakaf manfaat asuransi dan manfaat investasi pada asuransi jiwa syariah sehingga menjadikan mengikat isi fatwa tersebut bagi peminta fatwa. 
ljtihad: Jurnal Wacana Hukum Islam dan Kemanusiaan, Volume 17, No. 2, Desember 2017: 285-299

\section{Penutup}

Kedudukan hukum wakaf produktif melalui wakaf wasiat polis asuransi syariah menurut hukum Islam, yaitu termasuk wakaf produktif. Namun, dari sisi unsur kepemilikannya sebagai objek wakaf belum sepenuhnya dimiliki oleh wakif sehingga ini menjadikan perbedaan pendapat dikalangan ulama tentang kesahannya, walaupun secara prinsip telah dimiliki oleh wakif, namun masih membuka ruang sengketa karena objek wakaf tersebut belum dimiliki sepenuhnya. Akad wakaf wasiat polis asuransi syariah sendiri masih berpotensi dibatalkan oleh wakif maupun oleh pihak asuransi syariah salah satunya jika pihak wakif mendapatkan kesulitan dalam membayar premi sebelum jatuh tempo. Adapun implementasi wakaf produktif melalui wakaf wasiat polis asuransi syariah di Lembaga Wakaf Al-Azhar Jakarta belum sepenuhnya mengikuti aturan dalam Fatwa DSN MUI dikarenakan fatwa tersebut baru keluar diakhir 2016 dan disosialisasikan di awal 2017, sedangkan wakaf wasiat polis asuransi syariah ini sudah dikenal di masyarakat sejak 2012.

\section{Daftar pustaka}

Anwar, Syamsul. Studi Hukum Islam Kontemporer, Jakarta: RM Books, 2007.

Agustianto. Wakaf Uang dan Peningkatan Kesejahteraan Umat, Artikel Zona Ekonomi Islam. di publikasikan pada Agustus. 2010.

Al-Arif, M Nur Rianto. "Pemberdayaan Masyarakat Berbasis Wakaf Uang." Asy-Syir'ah, Fak.syariah UIN Kalijaga Vol.44 No.II (2010): 813-838.

Al-Kabisi, Muhammad Abid Abdullah. Hukum Wakaf. Jakarta: IIMaN Press, 2004.

Ash-Shan'aniy, Muhammad Ibn Ismail. Subul al-Saläm. Bandung: PT.Dipoenogoro, t.t.

Al-Utsaimin, Muhammad bin Shalih. Panduan wakaf, Hibah dan Wasiat menurut Al-Qur'an dan Sunnah. Jakarta: Pustaka Imam Asy-Syafii, 2008.

Al-Zuhaili, Wahbah. Al-Wacāya wa al-Waqf f̆ $\bar{\imath}$ al-Fiqh al-Islämī. Beirut: Dār al-Fikr al-Mu'àshir, 2007.

Baskan, Birol. Waqf System as a Redistribution Mechanism in Ottoman Empire. Chicago: Northwestern University Department of Political Science, 2002.

Budiman, Achmad Arief. "Akuntabilitas Lembaga Pengelola Wakaf “. Vol. 19, No.1, UIN Walisongo, Semarang, (Mei 2011): 75-102.

Fadhilah, Nur. "Sengketa Tanah Wakaf dan Trategi Penyelesaiannya", De Jure: Jurnal Syariah dan Hukum, Vol.3 No.1 Juni, STAIN Tulungagung, (Juni 2011): 71-85. 
Direktorat Pemberdayaan Wakaf dan Direktorat Jenderal Bimbingan Masyarakat Islam. Pedoman Pengelolaan Wakeaf Uang. Jakarta: Depag RI, 2008 . . Fikih Wakaf. Jakarta: Depag RI, 2007. . Paradigma Baru Wakaf di Indonesia. Jakarta: Depag RI, 2004,

Ghofur, Abdul. Hukum dan Praktik Perwakafan di Indonesia. Yogyakarta: Pilar Media, 2006. Habibi, Mohammad Luthfillah dkk. "Membangun Integrated Takaful dan Wakaf Model dalam Upaya Meningkatkan Kemanfaatan Pemegang Polis," Jurnal Al-Uqud Vol.1 No. 2, UIN Sunan Ampel, Surabaya. (July 2017): 139-155.

Ismanto, Kuat. Asuransi Syariah Tinjauan Asas-asas Hukum Islam. Yogyakarta: Pustaka Pelajar, 2009.

Medias, Fahmi. "Wakaf Produktif," Lariba, Jurnal Ekonomi Islam UII, Vol. IV, No.1 UII, (July 2010): 69-84.

Mubarok, Jaih. Wakaf Produktif. Bandung: Sembiosa, 2008.

Sabiq, Sayid. Fiqh al-Sunnah. Beirut: Dar al-Alamiyah, 2009.

Sari, Elsi Kartika. Pengantar Hukum Zakat dan Wakaf. Jakarta: Grasindo, 2006.

Sulistiani, Siska Lis. "Wakaf Polis Asuransi Perspektif Ekonomi Islam untuk Pemberdayaan Umat," Prosiding Snapp Unisba (Oktober 2016): 307.

Somantri, Gumilar Rusliwa. "Memahami Metode Kualitatif". MAKARA: Sosial Humaniora, Vol. 9, No. 2, (Desember 2005):57-65 .

Syalabi. Muhadarat al-Waqf wa al-Waciyyah. Al-Iskandariyah: Matba'ah Dar al-Ta'lif , 1957.

Tarmizi, Erwandi. Harta Haram Muamalat Kontemporer. Bogor: Berkah Mulia Insani, 2016.

Qohaf, Mundzir. Manajemen Wakaf Produktif. Jakarta: Khalifa, 2008. 


\section{Ijtihad \\ Vol. 17, No. 1, Juni 2017}

\section{Daftar isi}

Implementasi mā̄așid al-shari’ah sebagai solusi problematika sosial da n kemasyarakatan kontemporer

A. Bahruddin $\bullet$ 1-18

Kebijakan fiskal dan upaya mengatasi disparitas ekonomi perspektif Islam Agus Waluyo • 19-38

Penukaran tanah wakaf masjid agung Semarang dalam perspektif fikih istibdāl

Abmad Furqon • 39-60

Poligami di Indonesia dalam Perspektif CEDAW dan Mazhab Shafi'i

Qurrotul Ainiyah • 61-84

Penerapan nilai toleransi antar budaya dalam pelaksanaan hukum kewarisan Islam pada masyarakat perbatasan di Rao Pasaman Sumatera Barat

Nofiardi dan Syafwan Rozi $\bullet$ 85-112

Isbat nikah terpadu sebagai solusi memperoleh hak identitas hukum Ramdani Wabyu Sururie • 113-133

Analisis profesi hakim dalam epistemologi hukum Islam

Sakirman $135-154$ 